\title{
What is the impact of user preferences on the design of the hospital online registration system: An integrated approach
}

Chin-Feng Lin

National PingTung University

Yin-Chih Fu

Kaohsiung Medical University Chung Ho Memorial Hospital

Liang-Shiun Lin

Kaohsiung Medical University

Chen-Su Fu ( $\triangle$ csfu1223@gmail.com )

National Cheng Kung University https://orcid.org/0000-0003-3702-9061

\section{Research}

Keywords: hospital online registration system, means-end chain theory, Kano model

Posted Date: January 13th, 2020

DOl: https://doi.org/10.21203/rs.2.20640/v2

License: (c) (1) This work is licensed under a Creative Commons Attribution 4.0 International License. Read Full License 


\section{Abstract}

Background

An efficient registration system for all these types of Taiwan medical institutions will enable outpatients to register online and inform them of the best time to go to the hospital and when their turn for medical treatment is. Hence, understanding the outpatients'/users' actual needs is important for hospital managers to design a user-friendly registration system.

\section{Purpose}

This study, based on means-end chain (MEC) theory and the Kano model, aims to: 1) understand user preferences toward using a hospital online registration system by constructing the Kano-MEC hierarchical value map, and 2) deduce and formulate effective system planning and promotion strategies. Methodology/approach Mixed methods research was employed to collect data. A total of 16 hospital registration websites were examined and 34 in-depth interviews were conducted. All the interview transcripts were analyzed, and 16 attribute, 13 consequence, and 4 value variables were obtained for a final questionnaire design. A total of 376 valid samples were collected from a questionnaire survey to construct a Kano-MEC hierarchical value map.

Results

The Kano-MEC hierarchical value map depicts hospital online registration users' innermost thoughts and cognitive structure with regard to their attribute/consequence/value preferences and their attribute performance, as categorized by Kano's quality classifications.

\section{Conclusions}

The Kano-MEC map showed that "right-clicking the registration by department tab," "modifying or canceling one's appointment," "downloading doctor's schedule," "doctor introduction," "right-clicking the registration by doctor's name," and "instant messaging" are classified as Kano's one-dimensional attributes that can improve users' satisfaction and reduce their dissatisfaction by increasing quality fulfillment. Practice Implications Evidently, managers should focus on "right-clicking the registration by department tab," "modifying or canceling one's appointment," "downloading doctor's schedule," "doctor introduction," "rightclicking the registration by doctor's name," and "instant messaging" to formulate their system planning for enhancing the functions of their online registration system and increasing user satisfaction.

\section{Background}

Birth, aging, sickness, and death are unavoidable stages of life and connected with medical and health care. People aim to live healthy, wealthy, and prosperous lives. Therefore, establishing good social security and healthcare systems is important for governments. In 1995, Taiwan established the National Health Insurance $(\mathrm{NHI})$ system to ensure that its citizens have access to affordable medical treatment. The NHI system currently covers $99.6 \%$ of the population and has contracts with $93 \%$ of the country's hospitals and clinics 
[1]. The NHI system is well known around the world for its quality medical services and equal treatment guarantees. People can simply use their $\mathrm{NHI}$ card to make an appointment with their doctor via walk-in, telephone, or Internet registration. Through walk-in registration, people give their outpatient $\mathrm{NHI}$ card to the registration counter, pay the registration fee, and wait in line for their registered number to be called. Through telephone registration, people provide the outpatient's name, ID number, the doctor's name, and outpatient departments. Before medical treatment, outpatients should go to the hospital, show their $\mathrm{NHI}$ card, and pay the registration fee. However, outpatients are unable to make sure that the registration operator keys in the right information and appointment details; thus, some errors during registration may result in outpatients spending more time before they see a doctor. Internet (online) registration is the most convenient way to make an appointment with a doctor. People simply access the hospital registration system website, key in the outpatient information, and receive their registration number. At the time of their appointment, outpatients can go directly to the doctor and pay the registration and treatment fees after medical treatment.

Although people under $\mathrm{NHI}$ have access to good medical care, people still spend too much time waiting at the doctor's office [2]. Liu and Wu [3] indicated that the average waiting time for treatment is about 100, 72, 36 , and 30 minutes in medical centers, regional hospitals, district hospitals, and clinics, respectively. An efficient registration system for all these types of Taiwan medical institutions will enable outpatients to register online and inform them of the best time to go to the hospital and when their turn for medical treatment is. Shortening the waiting time for treatment is possible. Hence, understanding the outpatients'/users' actual needs is important for hospital managers to design a user-friendly registration system.

In the literature, means-end chain (MEC) theory originally proposed by Gutman [4] has been widely used to understand users' actual needs and wants $[5,6,7]$. This theory argues that when users determine to use a product or system, they would consider what they would acquire after using it. As a result, their preference for the product's/system's attributes becomes the focal point during their decision-making process. The underlying idea of MECs is that invisible chains exist in the innermost minds of users, linking a product's/system's attributes (As) preferred by users with consequences (Cs) and values (Vs) perceived by these users upon using these attributes [4]. Referring to Gutman [4], this study adopted MEC theory to understand outpatients'/users' innermost thoughts toward the online registration system provided by hospitals via $\mathrm{A}-\mathrm{C}-\mathrm{V}$ chain aggregation (namely, MECs). Although MEC theory can inform researchers and practitioners which attributes, consequences, and values are important to users, it is unable to explain which attributes are "attractive features," "indifferent features," and "must-have features." Therefore, this study further adopted the Kano model to reveal which attributes of an online registration system are highly prioritized by users by using Kano's quality classification (i.e., attractive, indifferent, must-be, onedimensional, and reverse quality). By integrating MEC theory and the Kano model, this study aims to 1) understand user preferences toward using a hospital online registration system by constructing the KanoMEC hierarchical value map (HVM) and 2) deduce and formulate effective system planning and promotion strategies.

\section{Literature Review}




\section{Means-end Chain (MEC) Theory}

Gutman [4] proposed the MEC model to depict the relationship between consumption behavior and personal value. Reynolds and Gutman [8] adopted the laddering technique originally developed by Hinkle [9] to uncover the implicit meanings in each MEC. The basic idea of MEC is that a product's attributes are the means through which consumers obtain consequences/feelings after consuming such attributes to achieve consumers' desired end state of being $[10,11,12,13]$. Therefore, each MEC contains three major components: attribute (A), consequence (C), and values (V). Each MEC includes three levels of abstractness. At the lowest level are attributes, which can be abstract, such as atmosphere and style, or concrete such as price and weight. At the next level are functional and psychosocial consequences. At the highest level are values, which could be instrumental or terminal. Aggregating individual MECs from customers enables researchers to form a tree diagram, namely, an HVM, which visualizes customers' innermost thinking toward a particular product or service. Today, MECs have become a representative theory to reveal consumers' innermost cognitive structure of a particular product/service [14]. In practice, MEC theory has been widely used to deal with issues in the retail, communication, tourism, and healthcare industries $[13,15,16,17]$.

\section{Kano Model}

Rooted in motivation-hygiene theory [18], the two-dimensional model, which maps customer satisfaction and product development, was proposed by Kano et al. [19]. The Kano model classifies customer preference into five categories: must-be quality, one-dimensional quality, attractive quality, indifferent quality, and reverse quality. In a quality evaluation, attributes in the must-be category can be viewed as the essential requirements that a product or service must possess to meet customer demands. If such attributes are well done, then customers take this for granted and their satisfaction level will not rise at all. However, if such attributes are missing or not well done, customers would view this product or service as incomplete and will be dissatisfied. In the one-dimensional category, customers will be satisfied if these attributes are fulfilled, but they will be dissatisfied if these attributes are not fulfilled. Attributes classified as indifferent quality will neither result in customer satisfaction or dissatisfaction nor influence customers' quality evaluation of the product or the service. In the attractive category, attributes are not normally expected by customers. Put another way, these attributes provide satisfaction if they are fulfilled, but do not cause dissatisfaction if they are not fulfilled. Moreover, a product or service that has particular attributes in the reverse category may lead to customer dissatisfaction. In practice, the Kano model is applied not only in quality control but also in the fields of product development, services, information, and healthcare [20, 21, 22, 23, 24, 25].

\section{Methods}

\section{Research Framework and Procedure}

This study adopted MEC theory to examine the preferences and cognitive appraisals of users toward the hospital online registration system and then utilized the Kano model to classify the attributes or features of 
the online registration system into Kano's five categories (i.e., one-dimensional, must-be, indifferent, attractive, and reverse quality). Through the use of the HVM derived from MEC theory and Kano's quality appraisal, the findings of this study can provide hospital managers with insightful information to formulate effective strategies with regard to system planning, webpage copywriting and design, and function design. Figure 1 illustrates the research framework of this study.

\section{Samples, Variables, Questionnaire Design, and Data Collection}

This study adopted one-on-one in-depth interviews to collect data for an MEC analysis. Thirty-four participants with experience using the hospital online registration system were recruited. Male and female participants were evenly split. Most of the participants were aged between 25 and 34 years old and are heavy Internet users in Taiwan [26]; this is also the main group that is familiar with the hospital online registration system. Each interview took roughly 45 minutes. The following are the main questions asked in each interview:

1. Please recall the hospital online registration system that you have used before. What are the names of the hospitals? Please provide detailed information for the one that impressed you the most and why.

2. Which attributes/features of the online registration system do you prefer the most? Why are they important to you? Please provide more information.

3. What consequences or feelings do you have when the online registration system offers such attributes? What would you feel if such attributes are not provided and why?

4. Which values can you achieve after using this system?

All interviews were audio recorded, transcribed, and conducted with permission from the participants. To ensure accuracy, the interview transcripts were content analyzed by using the terms identified in Table 1 and confirmed by each respondent. The extracted phrases from the transcripts were then coded into the appropriate categories of MEC as A, C, and V variables, as shown in Table 2. Thirty-three variables were gathered, including 16 attribute, 13 consequence, and 4 value variables. The percentage agreement and the reliability coefficient agreement among the three coders are $94.7 \%$ and $98.2 \%$, respectively, thereby indicating that the content analysis results are reliable [27]. 
Table 1

Variable definition

\begin{tabular}{|lll|}
\hline Item & Conceptual definition & Operational definition \\
\hline Attribute (A) & $\begin{array}{l}\text { A product's features or characteristics } \\
\text { are preferred by customers. }\end{array}$ & $\begin{array}{l}\text { The factors that people consider when using } \\
\text { the online registration system to make } \\
\text { doctor's appointments }\end{array}$ \\
\hline $\begin{array}{l}\text { Consequence } \\
(\mathrm{C})\end{array}$ & $\begin{array}{l}\text { Direct/indirect results of } \\
\text { positive/negative feelings after } \\
\text { consuming the product's attributes }\end{array}$ & $\begin{array}{l}\text { The direct or indirect results/feelings upon } \\
\text { using the online registration system }\end{array}$ \\
\hline Value $(\mathrm{V})$ & $\begin{array}{l}\text { Reflecting customers' needs and } \\
\text { desires and what they care about most } \\
\text { in life }\end{array}$ & $\begin{array}{l}\text { The psychological pursuit of the desired } \\
\text { states of being in life }\end{array}$ \\
\hline
\end{tabular}


Table 2

Variable, codes, and definition

\section{Code Attribute}

A1 Functional menu layout

A2 Q \& A

A3 Site map

A4 English interface

A5 Right-clicking the registration by department tab

A6 Modifying or canceling one's appointment

A7 Downloading doctor's schedule

A8 Doctor introduction

A9 Schedule change notices

A10 Department and clinic code

A11 Hospital floor layout

A12 Privacy notice of patients

A13 Right-clicking the registration by symptom of a disease

A14 Right-clicking the registration by Doctor's name

A15 Instant messaging

A16 App

Code Consequence

C1 Efficient

C2 Time-saving

C3 Convenience

C4 Vision design

C5 Causing offense

\section{Definition}

Menu of the hospital online registration system

Frequently asked questions about using the hospital online registration system

Visible page list on a site

Registration system offering an English interface

Making an appointment by clicking through the department tab

Modifying or canceling one's doctor's appointments

Doctor's schedule available online for downloading

Doctor introduction, including specialization, license, and experience

Schedule change notices such as doctor changed and clinic cancelled

Code for registration with department and clinic

Description of hospital floor layout

Patients required knowing before/after seeing a doctor

Making an appointment by clicking through the tab about one's symptom of a disease

Making an appointment by clicking through the tab of doctor's name

Instant messaging about the progress of clinic appointment number

App for hospital registration system

Definition

Operating in a way that users desire to obtain results

Reducing the amount of time needed to make an appointment

Ease of making a doctor's appointment

Visual enjoyment due to the good layout of the registration webpage

Causing users to feel upset or angry when using the registration system 


\begin{tabular}{|lll|}
\hline Code & Attribute & Definition \\
\hline C6 & Rich content & $\begin{array}{l}\text { The elements provided by the system are complete and } \\
\text { sufficient }\end{array}$ \\
\hline C7 & Availability & Features are available \\
\hline C8 & Not embarrassed & $\begin{array}{l}\text { System design does not make users embarrassed to use } \\
\text { it }\end{array}$ \\
\hline C9 & Useless & Not working \\
\hline C10 & Informative & Facilitates the acquisition of information \\
\hline C11 & Habitual & Can be used constantly \\
\hline C12 & Useful & Helps users register online \\
\hline C13 & Easy to use & User-friendly \\
\hline Code & Consequence & Definition \\
\hline V1 & A sense of security & A desired state where users can feel confident and safe. \\
\hline V2 & A sense of belonging & Acceptance felt by users as a member of the hospital \\
\hline V3 & A sense of enjoyment & Pleasure from enjoyable experiences \\
\hline V4 & A sense of satisfaction & Happiness from the achievement of fulfilling a need \\
\hline
\end{tabular}

With the use of the 33 variables from the 34 in-depth interviews, an MEC dot connection questionnaire was designed by arranging all the attribute, consequence, and value variables into three columns from the left to the right. All respondents were asked to choose which attributes in the first column were important to them and then draw a line to connect the dots from the attributes to the dots in the consequence and value columns to form their $\mathrm{A}-\mathrm{C}-\mathrm{V}$ chains for HVM construction. For Kano analysis, the functional/dysfunctional questions were designed by asking "How do you feel if this attribute (i.e., functional menu layout [A1], Q\&A [A2], ..., and App [A16]) is provided/not provided by the hospital online registration system?" All respondents were required to choose one of the following five levels: delighted, must-be, neutral, live with, and dislike. Therefore, the final questionnaire was designed to include one conditional question and four parts. The conditional question was used to validate that the respondent had used the online registration system before. The first part of the designed dot connection questionnaire was for the MEC analysis, and the second and third parts were the five-level Kano questionnaire, including functional and dysfunctional questions. The last part was designed to collect the respondents' demographic information, such as gender, age, and monthly income.

In this study, data were gathered via a paper-based questionnaire survey over three months in the summer of 2018. With ineffective or missing data eliminated from 500 collected questionnaires, a total of 376 valid samples with an effective recovery rate of $75.2 \%$ were used for further analysis. 


\section{MEC and Kano Analyses}

For MEC analysis, data collected from the dot connection-type questions that represent the $\mathrm{A}-\mathrm{C}$ and $\mathrm{C}-\mathrm{V}$ linkages and frequencies from 376 valid samples were tabulated into the summary implication matrix. In this work, 16 attribute, 13 consequence, and 4 value variables formed $260(16 \times 13+13 \times 4)$ active cells in the summary implication matrix, and the total number of linkages was 4,092. Displaying 4,092 A-C and C-V linkages in a single HVM is impossible because doing so would make the HVM too complex to read. Consequently, setting a cut-off value is essential before constructing the HVM. The basic idea for the cut-off value determination is the use of a relatively small number of cells in the summary implication matrix to represent a large portion of the total number of linkages $[5,11,14,28,29]$. A detailed discussion of cut-off point determination and related criteria was provided in Pieters et al. [28]. High linkage frequencies correspond to high importance of these linkages [14]. Therefore, for HVM construction, this study set the cutoff values at 22, 50, and 71 to represent weak, middle, and strong linkages, respectively. As shown in Table 3, the first cut-off value of 22 was set to construct the HVM because this level contained $74.8 \%$ of the $4,092 \mathrm{~A}-$ C-V linkages made by 376 respondents by using only $24.29 \%$ of all possible cells in the summary implication matrix. In other words, this HVM uncovered $74.8 \%$ of the overall information provided by the respondents but used only $24.29 \%$ of all possible cells in the matrix. A similar idea was applied to the second and third cut-off value determinations. 
Table 3

Cut-off value determination

\begin{tabular}{|llllll|}
\hline $\begin{array}{l}\text { Cut- } \\
\text { off }\end{array}$ & $\begin{array}{l}\text { No. of } \\
\text { active } \\
\text { cells }\end{array}$ & $\begin{array}{l}\text { No. of active cells } \\
\text { as a proportion of } \\
\text { all cells }\end{array}$ & $\begin{array}{l}\text { No. of active cells as a } \\
\text { proportion of all cells } \\
\text { mentioned at least once }\end{array}$ & $\begin{array}{l}\text { No. of } \\
\text { active } \\
\text { linkages }\end{array}$ & $\begin{array}{l}\text { No. of active } \\
\text { linkages as a } \\
\text { proportion of all } \\
\text { linkages }\end{array}$ \\
\hline 0 & 260 & $100 \%$ & & 4092 & \\
\hline 1 & 210 & $81 \%$ & $100.00 \%$ & 4092 & $100.00 \%$ \\
\hline 2 & 183 & $70 \%$ & $87.14 \%$ & 4065 & $99.34 \%$ \\
\hline 3 & 161 & $62 \%$ & $76.67 \%$ & 4021 & $98.26 \%$ \\
\hline$\ldots$ & $\ldots$ & $\ldots$ & $\ldots$ & $\ldots$ & $\ldots$ \\
\hline 21 & 52 & $20 \%$ & $24.76 \%$ & 3082 & $75.32 \%$ \\
\hline 22 & 51 & $20 \%$ & $24.29 \%$ & 3061 & $74.80 \%$ \\
\hline 23 & 50 & $19 \%$ & $23.81 \%$ & 3039 & $74.27 \%$ \\
\hline 24 & 49 & $19 \%$ & $23.33 \%$ & 3016 & $73.70 \%$ \\
\hline$\ldots$ & $\ldots$ & $\ldots$ & $\ldots$ & $\ldots$ & $\ldots$ \\
\hline 49 & 26 & $10 \%$ & $12.38 \%$ & 2208 & $53.96 \%$ \\
\hline 50 & 25 & $10 \%$ & $11.90 \%$ & 2159 & $52.76 \%$ \\
\hline 51 & 25 & $10 \%$ & $11.90 \%$ & 2159 & $52.76 \%$ \\
\hline$\ldots$ & $\ldots$ & $\ldots$ & $\ldots$ & 1861 & $45.48 \%$ \\
\hline 71 & 20 & $8 \%$ & $9.52 \%$ & $40.27 \%$ \\
\hline 72 & 17 & $7 \%$ & $8.10 \%$ & & $\ldots$ \\
\hline
\end{tabular}

For the Kano analysis, this study adopted the five-level Kano questionnaire (i.e., delighted, must-be, neutral, live-with, and dislike) and used the Kano evaluation table (Table 4) proposed by Matzler and Hinterhuber [30] to classify 16 attributes of the online registration system into one-dimensional, must-be, attractive, indifferent, and reverse quality. Furthermore, this study used customer satisfaction coefficient (see formulas 1 and 2) to evaluate which attributes can influence the satisfaction of online registration system users. 
Table 4

Kano evaluation table

\begin{tabular}{|c|c|c|c|c|c|c|}
\hline \multicolumn{2}{|c|}{ Customer requirements } & \multicolumn{5}{|c|}{ Attributes were not offered } \\
\hline & & $\begin{array}{l}\text { Delight } \\
5\end{array}$ & $\begin{array}{l}\text { Must-be } \\
4\end{array}$ & $\begin{array}{l}\text { Neutral } \\
3\end{array}$ & $\begin{array}{l}\text { Live-with } \\
2\end{array}$ & $\begin{array}{l}\text { Dislike } \\
1\end{array}$ \\
\hline \multirow[t]{5}{*}{$\begin{array}{l}\text { Attributes } \\
\text { were offered }\end{array}$} & Delight 5 & Questionable & Attractive & Attractive & Attractive & $\begin{array}{l}\text { One- } \\
\text { dimensional }\end{array}$ \\
\hline & $\begin{array}{l}\text { Must-be } \\
\text { that way } 4\end{array}$ & Reverse & Indifferent & Indifferent & Indifferent & Must-be \\
\hline & Neutral 3 & Reverse & Indifferent & Indifferent & Indifferent & Must-be \\
\hline & $\begin{array}{l}\text { Live-with it } \\
2\end{array}$ & Reverse & Indifferent & Indifferent & Indifferent & Must-be \\
\hline & Dislike 1 & Reverse & Reverse & Reverse & Reverse & Questionable \\
\hline
\end{tabular}

$$
\begin{aligned}
& \text { Extent of satisfaction: } \left.\frac{\mathrm{AQ}+\mathrm{OQ}}{\mathrm{AQ}+\mathrm{OQ}+\mathrm{MQ}+\mathrm{IQ}} \ldots \ldots \ldots \ldots \ldots \ldots \ldots \ldots \text { (Formula } 1\right) \\
& \text { Extent of dissatifaction: } \frac{\mathrm{OQ}+\mathrm{MQ}}{(\mathrm{AQ}+\mathrm{OQ}+\mathrm{MQ}+\mathrm{QQ}) \times(-1)} \ldots \ldots \ldots \ldots \ldots \ldots \text { (Formula 2) }
\end{aligned}
$$

Acronyms: must-be quality (MQ), one-dimensional quality (OQ), attractive quality (AQ), indifferent quality (IQ), and attractive quality (AQ)

\section{Results}

\section{Sample Description}

Among 376 valid samples (see Table 5), male and females occupied $39.36 \%$ and $60.64 \%$ of respondents, respectively. Approximately $36 \%$ of respondents were aged between 21 and 30 years old. A total of $67.29 \%$ respondents had a college or university degree. About $29 \%$ of them had a monthly income between NT\$30,001 and NT\$60,000 (US\$: NT\$ = 1:30) (Taiwan's GDP per capita is US\$24,402), while the next income group (less than $\$ 30,000$ ) accounted for $28.46 \%$. 
Table 5

Sample profile

\begin{tabular}{|c|c|c|c|c|c|c|c|}
\hline Item & Type & No. & $\%$ & Item & Type & No. & $\%$ \\
\hline \multirow[t]{2}{*}{ Gender } & male & 148 & $39.36 \%$ & \multirow[t]{2}{*}{ Children } & none & 225 & $59.84 \%$ \\
\hline & female & 228 & $60.64 \%$ & & yes & 151 & $40.16 \%$ \\
\hline \multirow[t]{5}{*}{ Age } & 20 and younger & 35 & $9.31 \%$ & \multirow{5}{*}{$\begin{array}{l}\text { No. of } \\
\text { children }\end{array}$} & 0 & 225 & $59.84 \%$ \\
\hline & $21-30$ & 136 & $36.17 \%$ & & 1 & 38 & $10.11 \%$ \\
\hline & $31-40$ & 56 & $14.89 \%$ & & 2 & 88 & $23.40 \%$ \\
\hline & $41-50$ & 78 & $20.74 \%$ & & 3 & 16 & $4.26 \%$ \\
\hline & 51and older & 71 & $18.88 \%$ & & 4 and more & 9 & $2.39 \%$ \\
\hline \multirow[t]{5}{*}{$\begin{array}{l}\text { Monthly income } \\
\text { (USS:NTDS=1:30) }\end{array}$} & Less than $\$ 30000$ & 107 & $28.46 \%$ & \multirow[t]{5}{*}{ Education } & $\begin{array}{l}\text { Junior high } \\
\text { school or } \\
\text { less }\end{array}$ & 6 & $1.60 \%$ \\
\hline & $\$ 30001 \sim \$ 60000$ & 109 & $28.99 \%$ & & $\begin{array}{l}\text { High school } \\
\text { \& vocational } \\
\text { school }\end{array}$ & 64 & $17.02 \%$ \\
\hline & $\$ 60001 \sim \$ 90000$ & 60 & $15.96 \%$ & & $\begin{array}{l}\text { College \& } \\
\text { University }\end{array}$ & 253 & $67.29 \%$ \\
\hline & $\$ 90001 \sim \$ 120000$ & 58 & $15.43 \%$ & & \multirow{2}{*}{$\begin{array}{l}\text { Master and } \\
\text { Ph.D. }\end{array}$} & \multirow[t]{2}{*}{53} & \multirow[t]{2}{*}{$14.10 \%$} \\
\hline & $\begin{array}{l}\text { More than } \\
\$ 120000\end{array}$ & 42 & $11.17 \%$ & & & & \\
\hline
\end{tabular}

\section{HVM of the Hospital Online Registration System}

In Fig. 2, the dotted line (weak linkage) indicates that a cut-off value of 22 was set for an HVM construction by using $\mathrm{A}-\mathrm{C}$ and $\mathrm{C}-\mathrm{V}$ linkage frequencies of 22 or higher in the summary implication matrix. For example, "app (A16)" provides users with "useful (C12)" feelings after using the online registration system, yielding "a sense of satisfaction (V3)," that is, hospital online registration system managers should promote that their app is useful and meets the satisfaction of users. Given that a high linkage frequency represents the high importance of the linkage, this study mainly focused on the discussion of those important (strong) linkages. The bold lines (see Fig. 2) with a cut-off value of 71 represent that these A-C-V linkages are perceived as important by 376 respondents. "Functional menu layout (A1)," for instance, causes users to perceive that the system is "efficient (C1)" and leads to their "sense of security (V1)." In addition, users prefer "right-clicking the registration by department tab (A5)" and "modifying or canceling one's appointment (A6)" provided by the hospital's online system, because these attributes can produce a "convenience (C3)" benefit, achieving their psychological state of "security (V1)," "enjoyment (V2)," and "satisfaction (V3)." If a hospital's registration system has the "downloading doctor's schedule (A7)" attribute, then this attribute can make users perceive the "convenience (C3)" and "availability (C7)" of the system and thereby achieve "security 
(V1)," "enjoyment (V2)," and "satisfaction (V3)." Moreover, "doctor's introduction (A8)" causes users to perceive that the system is "informative (C10)" and further leads to their "sense of satisfaction (V3)." "Rightclicking the registration by symptom of a disease (A13)" makes patients feel "not embarrassed (C8)" to register online and thus arouses the users' "sense of satisfaction (V3)." Furthermore, the "instant messaging (A15)" attribute provided by the hospital online registration system not only provides users with "time-saving (C2)" and "easy-to-use (C13)" benefits but also gives users "a sense of security (V1)" and "a sense of enjoyment (V4)." Hospital managers should focus on "functional menu layout (A1)," "right-clicking the registration by department tab (A5)," "modifying or canceling one's appointment (A6)," "downloading doctor's schedule (A7)," "doctor's introduction (A8)," "right-clicking the registration by symptom of a disease (A13)," and "instant messaging (A15)" in creating an online registration system, because these attributes are the most important features that encourage patients to make an appointment with doctors online.

\section{Kano Classification of User's Perceptions toward Hospital Online Registration System}

\section{Kano analysis}

Witell and Löfgren [31] empirically confirmed that the five-level Kano questionnaire is the most effective measurement for the classification of quality attributes. In this study, attribute data gathered from five-level Kano questionnaire were statistically analyzed and summarized in Table 6 . The percentages of each row represent the results of the quality appraisals from 376 respondents. The highest percentage indicates the particular attribute belonging to that particular Kano classification, termed the first-priority attributes of Kano's quality classification. The second highest percentage attribute is named the second-priority attributes of Kano's quality classification. 
Kano classification

\begin{tabular}{|c|c|c|c|c|c|c|c|c|c|}
\hline \multirow[t]{2}{*}{ Code } & \multirow[t]{2}{*}{ Attribute } & \multirow[t]{2}{*}{$\mathrm{AQ}$} & \multirow[t]{2}{*}{ IQ } & \multirow[t]{2}{*}{ RQ } & \multirow[t]{2}{*}{ MQ } & \multirow[t]{2}{*}{ QQ } & \multirow[t]{2}{*}{$\mathrm{OQ}$} & \multicolumn{2}{|c|}{$\begin{array}{l}\text { Quality } \\
\text { classification }\end{array}$} \\
\hline & & & & & & & & $\begin{array}{l}\text { 1st } \\
\text { priority }\end{array}$ & $\begin{array}{l}\text { 2nd } \\
\text { priority }\end{array}$ \\
\hline $\mathrm{A} 1$ & $\begin{array}{l}\text { Functional } \\
\text { menu layout }\end{array}$ & $9.90 \%$ & $33.10 \%$ & $0.50 \%$ & $27.70 \%$ & $0.80 \%$ & $28.00 \%$ & IQ & $\mathrm{OQ}$ \\
\hline A2 & $\mathrm{Q} \& \mathrm{a}$ & $20.50 \%$ & $49.40 \%$ & $0.80 \%$ & $10.40 \%$ & $0.80 \%$ & $18.10 \%$ & IQ & $A Q$ \\
\hline A3 & Site map & $12.50 \%$ & $48.60 \%$ & $0.50 \%$ & $17.60 \%$ & $0.50 \%$ & $20.30 \%$ & IQ & $\mathrm{OQ}$ \\
\hline A4 & $\begin{array}{l}\text { English } \\
\text { interface }\end{array}$ & $12.30 \%$ & $67.50 \%$ & $1.30 \%$ & $8.80 \%$ & $0.50 \%$ & $9.60 \%$ & IQ & $A Q$ \\
\hline A5 & $\begin{array}{l}\text { Right- } \\
\text { clicking the } \\
\text { registration } \\
\text { by } \\
\text { department } \\
\text { tab }\end{array}$ & $7.20 \%$ & $9.90 \%$ & $0.50 \%$ & $30.70 \%$ & $0.50 \%$ & $51.20 \%$ & $\mathrm{OQ}$ & MQ \\
\hline A6 & $\begin{array}{l}\text { Modifying or } \\
\text { canceling } \\
\text { one's } \\
\text { appointment }\end{array}$ & $6.70 \%$ & $13.30 \%$ & $0.30 \%$ & $32.50 \%$ & $1.60 \%$ & $45.60 \%$ & $\mathrm{OQ}$ & MQ \\
\hline A7 & $\begin{array}{l}\text { Downloading } \\
\text { doctor's } \\
\text { schedule }\end{array}$ & $4.50 \%$ & $10.90 \%$ & $0.30 \%$ & $35.20 \%$ & $0.50 \%$ & $48.60 \%$ & $\mathrm{OQ}$ & MQ \\
\hline A8 & $\begin{array}{l}\text { Doctor } \\
\text { introduction }\end{array}$ & $12.50 \%$ & $25.10 \%$ & $0.80 \%$ & $27.50 \%$ & $0.50 \%$ & $33.60 \%$ & $\mathrm{OQ}$ & MQ \\
\hline A9 & $\begin{array}{l}\text { Schedule } \\
\text { change } \\
\text { notices }\end{array}$ & $12.30 \%$ & $49.50 \%$ & $0.50 \%$ & $19.50 \%$ & $1.10 \%$ & $17.10 \%$ & IQ & MQ \\
\hline A10 & $\begin{array}{l}\text { Department } \\
\text { \& clinic code }\end{array}$ & $8.80 \%$ & $43.00 \%$ & $0.50 \%$ & $21.90 \%$ & $0.90 \%$ & $24.90 \%$ & IQ & $\mathrm{OQ}$ \\
\hline A11 & $\begin{array}{l}\text { Hospital } \\
\text { floor layout }\end{array}$ & $10.20 \%$ & $36.50 \%$ & $0.30 \%$ & $27.30 \%$ & $1.10 \%$ & $24.60 \%$ & IQ & MQ \\
\hline A12 & $\begin{array}{l}\text { Privacy } \\
\text { notice of } \\
\text { patients }\end{array}$ & $14.70 \%$ & $50.50 \%$ & $1.30 \%$ & $17.20 \%$ & $0.50 \%$ & $15.80 \%$ & IQ & MQ \\
\hline
\end{tabular}

Note: 1) AQ: attractive quality; IQ: indifferent quality; MQ: must-be quality; OQ: one-dimensional quality; 2) Figures in the shade of dark grey represent that the relative accumulated frequency is the highest in the row. 


\begin{tabular}{|c|c|c|c|c|c|c|c|c|c|}
\hline \multirow[t]{2}{*}{ Code } & \multirow[t]{2}{*}{ Attribute } & \multirow[t]{2}{*}{$\mathrm{AQ}$} & \multirow[t]{2}{*}{ IQ } & \multirow[t]{2}{*}{$\mathrm{RQ}$} & \multirow[t]{2}{*}{ MQ } & \multirow[t]{2}{*}{ QQ } & \multirow[t]{2}{*}{ OQ } & \multicolumn{2}{|c|}{$\begin{array}{l}\text { Quality } \\
\text { classification }\end{array}$} \\
\hline & & & & & & & & $\begin{array}{l}\text { 1st } \\
\text { priority }\end{array}$ & $\begin{array}{l}\text { 2nd } \\
\text { priority }\end{array}$ \\
\hline A13 & $\begin{array}{l}\text { Right- } \\
\text { clicking the } \\
\text { registration } \\
\text { by symptom } \\
\text { of a disease }\end{array}$ & $12.00 \%$ & $13.10 \%$ & $0.50 \%$ & $27.50 \%$ & $0.80 \%$ & $46.10 \%$ & $\mathrm{OQ}$ & MQ \\
\hline A14 & $\begin{array}{l}\text { Right- } \\
\text { clicking the } \\
\text { registration } \\
\text { by doctor's } \\
\text { name }\end{array}$ & $10.10 \%$ & $36.50 \%$ & $1.10 \%$ & $25.10 \%$ & $1.30 \%$ & $25.90 \%$ & IQ & $\mathrm{OQ}$ \\
\hline A15 & $\begin{array}{l}\text { Instant } \\
\text { messaging }\end{array}$ & $12.50 \%$ & $9.60 \%$ & $0.30 \%$ & $22.20 \%$ & $1.30 \%$ & $54.10 \%$ & $\mathrm{OQ}$ & MQ \\
\hline A16 & App & $22.10 \%$ & $37.10 \%$ & $0.50 \%$ & $9.60 \%$ & $0.80 \%$ & $29.90 \%$ & IQ & $\mathrm{OQ}$ \\
\hline
\end{tabular}

\section{First-priority attributes of Kano's quality classification}

1. One-dimensional quality $(\mathrm{OQ})$

For users, the attributes of an online registration system are classified as one-dimensional quality, which represents that user satisfaction will increase if the quality performance is good. By contrast, bad performance decreases satisfaction. As shown in the first-priority column with the symbol OQ, "right-clicking the registration by department tab (A5) (51.2\%)," "modifying or canceling one's appointment (A6) (45.6\%)," "downloading doctor's schedule (A7) (48.5\%)," "doctor introduction (A8) (33.6\%)," "right-clicking the registration by doctor's name (A13) (46.0\%)," and "instant messaging (A15) (54.1\%)" are classified as onedimensional quality. Thus, the managers of hospital registration systems should pay more attention to the improvement of these attributes.

2. Must-be quality (MQ)

None of the 16 attributes was classified as must-be quality in the first-priority Kano classification, which indicates that users believe the hospital online registration system must have these attributes. User satisfaction will not increase because the system provides these must-be attributes. However, user satisfaction will decrease dramatically if these attributes are not provided.

3. Attractive quality (AQ) 
None of the 16 attributes fell under attractive quality. If the system does not have such attributes, users will not feel dissatisfied or disappointed [32].

4. Indifferent quality (IQ)

Whether the online registration system provides the attributes with indifferent quality will not result in user satisfaction or dissatisfaction. In this study, the following 10 attributes are classified as indifferent quality: "functional menu layout (A1) (33.1\%)," "Q\&A (A2) (49.3\%)," "right-clicking the registration by symptom of a disease (A3) (48.5\%)," "English interface (A4) (67.5\%)," "schedule change notices (A9) (49.5\%)," "department and clinic code (A10) (43.0\%)," "hospital floor layout (A11) (36.6\%)," "privacy notice of patients (A12) (50.5\%)," "right-clicking the registration by doctor's name (A14) (36.5\%)," and "app (A16) (37.1\%)."

\section{Reverse quality (RQ)}

Attributes in the reverse category may lead to user dissatisfaction if the system provides such attributes. In this study, none of the 16 attributes was classified under reverse quality.

\section{Second-priority attributes of Kano's quality classification}

In the first-priority Kano's quality classification, 10 out of 16 attributes were in the indifferent category, showing that user satisfaction would not be influenced by these 10 attributes. Therefore, this study further examined the second highest percentage in each row to find the second-priority attribute quality classification of each attribute. As shown in the last column (second-priority quality classification) of Table 6 , a total of 9,2 , and 5 items of attributes were grouped in the must-be, attractive, and one-dimensional categories, respectively.

1. Must-be quality (MQ)

In the second-priority quality classification, "right-clicking the registration by department tab (A5) (30.7\%)," "modifying or canceling one's appointment (A6) (32.5\%)," "downloading doctor's schedule (A7) (35.2\%)," "doctor introduction (A8) (27.5\%)," "schedule change notices (A9) (19.5\%)," "hospital floor layout (A11) (23.63\%)," "right-clicking the registration by doctor's name (A13) (27.5\%)," and "instant messaging (A15) (22.1\%)."

\section{Attractive quality (AQ)}

“Q\&A (A2) (25.50\%)" and "English interface (A4) (12.30\%)" were grouped as attractive quality in the secondary quality classification.

3. One-dimensional quality (OQ)

Five attributes were categorized as one-dimensional quality: "functional menu layout (A1) (28.0\%)," "rightclicking the registration by symptom of a disease (A3) (20.3\%)," "department and clinic code (A10) (24.9\%)," "right-clicking the registration by doctor's name (A14) (25.9\%)," and "app (A16) (29.9\%)." 
On the basis of the second-priority quality classification, improving attributes in the attractive and onedimensional categories can increase user satisfaction, while attributes in the must-be category are essential features for an online registration system.

\section{Kano's Customer Satisfaction Coefficient}

To understand the relation between online registration system users' satisfaction/dissatisfaction if their requirements are met/unmet and the priority of these requirements in the Kano model, this study adopted Kano's customer satisfaction coefficient to reveal the most important quality element for increasing satisfaction. As shown in Table 7, "instant messaging (A15) (0.678)," "right-clicking the registration by department tab (A5) (0.590)," and "right-clicking the registration by symptom of a disease (A3) (0.588)" are the top three most important quality attributes for increasing satisfaction. Notably, A15, A5, and A3 are classified as one-dimensional quality, thereby indicating that a high satisfaction index ( $\mathrm{SI}$ ) corresponds to the high influence of the satisfaction level. With regard to the extent of dissatisfaction indices (DSIs), the negative sign represents a negative impact on user satisfaction if these attributes are unmet. Table 7 shows that "downloading doctor's schedule (A7) (-0.844)," "right-clicking the registration by department tab (A5) $(-0.827)$, " and "modifying or canceling one's appointment (A6) $(-0.776)$ " are the top three quality attributes for decreasing the dissatisfaction level. Similarly, A7, A5, and A6 are also grouped under one-dimensional quality, thereby indicating that a high absolute value of the DSI corresponds to high dissatisfaction if the attribute does not meet the requirement of users. Interestingly, "right-clicking the registration by department tab (A5)" has high SI and DSI, thereby indicating that this attribute should be viewed as the core component that can effectively satisfy system users if its performance is met. 
Table 7

Customer satisfaction coefficient

\begin{tabular}{|c|c|c|c|c|c|}
\hline \multirow[t]{2}{*}{ Code } & \multirow[t]{2}{*}{ Attribute } & \multicolumn{2}{|c|}{$\begin{array}{l}\text { Quality } \\
\text { classification }\end{array}$} & \multirow[t]{2}{*}{$\begin{array}{l}\text { Extent of } \\
\text { satisfaction }\end{array}$} & \multirow[t]{2}{*}{$\begin{array}{l}\text { Extent of } \\
\text { dissatisfaction }\end{array}$} \\
\hline & & $\begin{array}{l}\text { 1st } \\
\text { priority }\end{array}$ & $\begin{array}{l}\text { 2nd } \\
\text { priority }\end{array}$ & & \\
\hline A1 & Functional menu layout & IQ & $\mathrm{OQ}$ & 0.384 & -0.565 \\
\hline A2 & $Q \& A$ & IQ & $A Q$ & 0.393 & -0.290 \\
\hline A3 & Site map & IQ & $\mathrm{OQ}$ & 0.332 & -0.383 \\
\hline A4 & English interface & IQ & $A Q$ & 0.223 & -0.188 \\
\hline A5 & $\begin{array}{l}\text { Right-clicking the registration by } \\
\text { department tab }\end{array}$ & $\mathrm{OQ}$ & MQ & 0.590 & -0.827 \\
\hline A6 & $\begin{array}{l}\text { Modifying or canceling one's } \\
\text { appointment }\end{array}$ & $\mathrm{OQ}$ & MQ & 0.533 & -0.796 \\
\hline A7 & Downloading doctor's schedule & $\mathrm{OQ}$ & MQ & 0.535 & -0.844 \\
\hline A8 & Doctor introduction & $\mathrm{OQ}$ & MQ & 0.468 & -0.619 \\
\hline A9 & Schedule change notices & IQ & MQ & 0.299 & -0.372 \\
\hline A10 & Department \& clinic code & IQ & $\mathrm{OQ}$ & 0.341 & -0.474 \\
\hline A11 & Hospital floor layout & IQ & MQ & 0.352 & -0.526 \\
\hline A12 & Privacy notice of patients & IQ & MQ & 0.311 & -0.335 \\
\hline A13 & $\begin{array}{l}\text { Right-clicking the registration by } \\
\text { symptom of a disease }\end{array}$ & $\mathrm{OQ}$ & MQ & 0.588 & -0.745 \\
\hline A14 & $\begin{array}{l}\text { Right-clicking the registration by } \\
\text { doctor's name }\end{array}$ & IQ & $\mathrm{OQ}$ & 0.369 & -0.522 \\
\hline A15 & Instant messaging & $\mathrm{OQ}$ & MQ & 0.678 & -0.775 \\
\hline A16 & App & IQ & $\mathrm{OQ}$ & 0.527 & -0.400 \\
\hline
\end{tabular}

Figure 3 illustrates the impact on overall satisfaction with quality defined by the SI value on the $x$-axis and the absolute DSI value on the $y$-axis. Referring to Yao et al. [20], when the attribute quality is far from the origin point $(0,0)$, such an attribute has a greater influence on satisfaction. As shown in Part I of Fig. 3 (both $\mathrm{SI}$ and absolute DSI values greater than 0.5$)$, "right-clicking the registration by department tab (A5)," "modifying or canceling one's appointment (A6)," "downloading doctor's schedule (A7)," "right-clicking the registration by doctor's name (A13)," and "instant messaging (A15)" are classified as one-dimensional attributes that can improve users' satisfaction and reduce their dissatisfaction by increasing quality 
fulfillment. In Part II of Fig. 3 (SI value greater than 0.5 but absolute DSI value less than 0.5), "app (A16)” is the only attribute located in this section. If the quality of "app (A16)" is met, then it would have a greater influence on user satisfaction improvement but less influence on dissatisfaction decrease. By contrast, "functional menu layout (A1)," "doctor introduction (A8)," "hospital floor layout (A11)," and "right-clicking the registration by doctor's name (A14)" are attributes in Part III of Fig. 3 (absolute DSI value greater than 0.5 but SI value less than 0.5 ) that would have greater impact on reducing user dissatisfaction but less impact on increasing user satisfaction if quality fulfillment increases. The rest of the attributes $(A 2, A 3, A 4, A 9, A 10$, and A12) in Part IV of Fig. 3 (SI and absolute DSI values less than 0.5 ) have little impact on user satisfaction and dissatisfaction. Thus, improving the quality of these attributes might not be necessary.

\section{Discussion}

This study integrated the MEC and Kano models to reveal users' preferences and perceptions toward the online registration system of hospitals. Through the integration of these two models, researchers can not only understand the implications of each $\mathrm{A}-\mathrm{C}-\mathrm{V}$ linkage of MEC but also further gain insight into the Kano's quality classification of each attribute to provide hospital managers with insightful information for formulating effective system design and promotion strategies.

\section{User preferences for online registration system design}

Figure 4 illustrates the results of integrating the MEC and Kano analyses. For MEC analysis, strong linkages correspond to increased importance of the linkages. Consequently, "functional menu layout (A1)," "rightclicking the registration by department tab (A5)," "modifying or canceling one's appointment (A6)," "downloading doctor's schedule (A7)," "doctor introduction (A8)," "right-clicking the registration by doctor's name (A13)," and "instant messaging (A15)" are the most important attributes perceived by the users of the hospital online registration system. Kano analysis indicates that users will have a high level of satisfaction if a product has more one-dimensional attributes or if such attributes have better performance. Through an integration of the strong linkages and one-dimensional classification, attributes highlighted with an orange box in Figure 4 (i.e., A5, A6, A7, A8, A13, and A15) should evidently be the focus of online registration system design. The use of attributes can yield "time-saving (C2)," "convenience (C3)," "availability (C7)," "not embarrassed (C8)," "informative (C10)," and "easy to use (C13)" feelings and lead to the achievement of "a sense of security (V1), "a sense of enjoyment (V4)," and "a sense of satisfaction (V3)."

\section{Attribute quality classification and user cognitive structure}

On the left-hand side of Figure 4, each attribute is classified as indifferent, attractive, one-dimensional, or must-be quality by the respondents' first or second priority order. First and second priorities represent that at least $33 \%$ and $12 \%$ of respondents have the same point of view and classified the attribute into its related Kano's quality classification, respectively. In Figure 4, six attributes (A1, A2, A3, A10, A11, and A16) are listed as first priority and classified as indifferent quality, but four of them (A1, A3, A10 and A16) listed as second priority were classified as one-dimensional quality, that is, system designers still need to pay attention to 
"functional menu layout (A1)," site map (A3)," "department and clinic code (A10)," and "app (A16)" attributes, given that the performance of these attributes is highly related to customer satisfaction. Notably, "Q\&A (A2)" in the second priority was grouped under attractive quality, representing that this attribute may produce additional satisfaction to users. "Hospital floor layout (A11)" in the second priority was classified as must-be quality, showing that at least $12 \%$ of respondents recognize this attribute as an essential feature of a registration system; without this attribute, they will feel the system is incomplete.

\section{Conclusion}

\section{System planning}

This study found that "right-clicking the registration by department tab (A5)," "modifying or canceling one's appointment (A6)," "downloading doctor's schedule (A7)," "doctor introduction (A8)," "right-clicking the registration by doctor's name (A13)," and "instant messaging (A15)" are classified as one-dimensional quality in the first priority and as must-be quality in the second priority, which means that they are important for registration system design. Given that at least $33 \%$ of respondents viewed these attributes as onedimensional quality, the high performance of these attributes corresponds to increased user satisfaction, and vice versa. These attributes were also classified under must-be quality, which means that if such attributes are missing, then users will be dissatisfied. Evidently, managers should focus on these attributes ( $A 5, A 6, A 7, A 8, A 13$, and A15) to formulate their system planning for enhancing the functions of their online registration system and increasing user satisfaction.

\section{Promotion strategy}

On the basis of the Kano-MEC hierarchical map (Figure 4), "efficient (C1)," "time-saving (C2)," "convenience (C3)," "availability (C7)," "not embarrassed (C8)," "informative (C10)," and "easy to use (C13)" are important consequences/benefits that users perceived upon utilizing the attributes of the registration system. Such consequences or benefits strongly link to "a sense of security (V1)," "a sense of enjoyment (V4)," and "a sense of satisfaction (V3)," showing that users' values can be achieved via the consequences/benefits of using the attributes. As a result, hospitals can promote these benefits of using an online registration system to reduce the personal costs of hospital registration.

\section{List Of Abbreviations}




\begin{tabular}{ll}
\hline \hline Abbreviation & Full form \\
\hline A & Attribute \\
A-C-V & Attribute-consequence-value \\
AQ & Attractive quality \\
C & Consequence \\
DSI & Dissatisfaction index \\
HVM & Hierarchical value map \\
IQ & Indifferent quality \\
MEC & Means-end Chain \\
MQ & Must-be quality \\
OQ & One-dimensional quality \\
RQ & Reversal quality \\
SI & Satisfaction index \\
V & Value \\
\hline \hline
\end{tabular}

\section{Declarations}

Ethics approval and consent to participate (Not applicable)

Consent for publication (Not applicable)

Availability of data and materials (The datasets used and/or analyzed during the current study are available from the corresponding author on reasonable request.)

Competing interests (The authors declare that they have no competing interests)

Funding (None)

Authors' contributions (YC examined and interpreted the data that were collected and analyzed by LS. CF summarized the results and constructed the figures. CS wrote the manuscript. All authors have read and approved the final manuscript.)

Acknowledgements (None)

\section{References}

[1] HWD (Health and Welfare Department of Taiwan) (2017) National health insurance system. Retrieved on 2018-08-24. Available at https://www.ey.gov.tw/state/News_Content3.aspx?

$\mathrm{n}=$ DB4C52986CA11472\&s=F82C9B04EBAC1080

[2] Lai SB, Yen YS. An empirical study of the impact of consumer's repeat purchase intentions on web-based self-service. Electron Comm Stud (Chinese version). 2004; 2: 259-78.

[3] Liu TC, Wu PC. The choice of medical institutions under NHI-an example of pediatric patients in Taipei. $J$ Healthcare Manag (Chinese version). 2001; 2: 87-108.

[4] Gutman J. A means-end chain model based on consumer categorization process. J Market. 1982; 46: 6072. 
[5] Lin CF, Fu CS. Implications of integrating e-leisure constraints and means-end hierarchies of young people's perceptions toward video-sharing websites. Online Inf Rev. 2018; 42: 355-71. doi: 10.1108/OIR-032017-0091

[6] Doucette WR, Wiederholt JB. Measuring product meaning for prescribed medication using a means-end chain model. J Health Care Mark. 1992; 12: 48-54.

[7] Bagozzi RP, Dabholkar PA. Discursive psychology: An Alternative conceptual foundation to means-end chain theory. Psychol Mark. 2000; 17: 535-86.

[8] Reynolds TJ, Gutman J. Laddering theory, method, analysis, and interpretation. J Advert Res. 1988; 28: 1131.

[9] Hinkle D. The change of personal constructs from the viewpoint of theory of construct implications. Unpublished doctoral dissertation, Ohio State University, Columbus, Ohio. 1965.

[10] Jeng MY, Yeh TM. The effect of consumer values on the brand position of green restaurants by meansend chain and laddering interviews. Serv Bus. 2016; 10: 223-38.

[11] Jiang S, Scott N, Ding P. Using means-end chain theory to explore travel motivation: An examination of Chinese outbound tourists. J. Vacat Mark. 2015; 21: 87-100.

[12] Lin CF, Fu CS Advancing the laddering and critical incident techniques by incorporating dramaturgical theory to reveal restaurant niches. Serv Ind J. 2017; 37: 801-818.

[13] Jung $\mathrm{Y}$, Kang $\mathrm{H}$. User goals in social virtual worlds: A means-end chain approach. Comput Human Behav. 2010; 26: 218-225.

[14] Lin CF, Fu CS, Chen YT. Exploring customer perceptions toward different service volumes: An integration of means-end chain and balance theories. Food Qual Prefer. 2019; 73: 86-96.

[15] Xiao L, Guo Z, Ambra JD. Analyzing consumer goal structure in online group buying: A means-end chain approach. Inform Manage. 2017; 54: 1097-1119.

[16] Klenosky DB. The "pull" of tourism destinations: A means-end investigation. J Travel Res. 2002; 40: 85395.

[17] Hamouri SM. User experience value system on social network sites of healthcare providers and its relation to users' perception of quality, Doctor of Philosophy thesis, Department of Business and Management, University of Wollongong, 2016. http://ro.uow.edu.au/theses/4800 Accessed Dec 182017.

[18] Herzberg F, Bernard M, Snyderman BB. The motivation to work. New York: Wiley. 1959.

[19] Kano, N., Seraku, N., Takahashi, F. and Tsjui, S. Attractive quality and must-be quality. Hinshitsu. 1984; 14: 147-56. 
[20] Yao ML, Chuang MC, Hsu CC. The Kano model analysis of features for mobile security application. Comput Secur. 2018; 78: 336-46.

[21] Ma MY, Chen CW, Chang YM. Using Kano model to differentiate between future vehicle-driving services. Int J Ind Ergon. 2019; 69: 142-152. doi:10.1016/j.ergon.2018.11.003.

[22] Chiang TL,Yi CY, Cheng $\mathrm{CH}$. An empirical study of applying Kano model and TRIZ business evolution trends to improve e-commerce service quality. 2013 IEEE International Conference on Service Operations and Logistics, and Informatics, Dongguan, China, 28-30 July 2013, pp.340-344. doi: 10.1109/SOLI.2013.6611437

[23] Hussain A, Mkpojiogu EOC, Kamal FM. Eliciting user satisfying requirements for an e-health awareness system using Kano model. Proceedings of the 14th WSEAS International Conference on Computer and Computational Science (ACACOS'15), Kuala Lumpur. 2015; pp. 156-165.

[24] Hussain A, Mkpojiogu EOC. An application of Kano method in the elicitation of stakeholder satisfying requirements for an e-Ebola awareness system. International J Sys App, Eng Develop. 2016; 10: 169-78.

[25] Vassiliadis CA, Fotiadis AK, Tavlaridou E. The effect of creating new secondary health services on patients' perceptions: A Kano service quality analysis approach. Total Qual Manag Bus. 2014; 25: 897-907. doi: 10.1080/14783363.2014.904564

[26] Statista. Daily internet usage rate in Taiwan in 2016, by age group. Retrieved from https://www.statista.com/statistics/348224/daily-internet-usage-age-group-taiwan/ Accessed Nov 232017.

[27] Kassarjian HH. Content analysis in consumer research. J Consumer Res. 1997; 4: 8-18.

[28] Pieters R, Baumgartner H, Allen D. A means-end chain approach to consumer goal structures. Int Res J Mark. 1995; 12: 227-44.

[29] Wang EST, Yu JR. Means-end chain approach for exploring the motivation of ready-to-drink tea consumers. Asia Pacific J Mark Logistics. 2016; 28: 384-95.

[30] Matzler $\mathrm{K}$, Hinterhuber $\mathrm{HH}$. How to make product development projects more successful by integrating Kano's model of customer satisfaction into quality function deployment. Technovation. 1998;18: 25-38.

[31] Witell L, Löfgren M. Classification of quality attributes. Manag Serv Qual. 2007; 17: 54-73.

[32] Löfgren M, Witell L. Kano's theory of attractive quality and packaging. Qual Manag J. 2005; 12: 7-20.

\section{Figures}




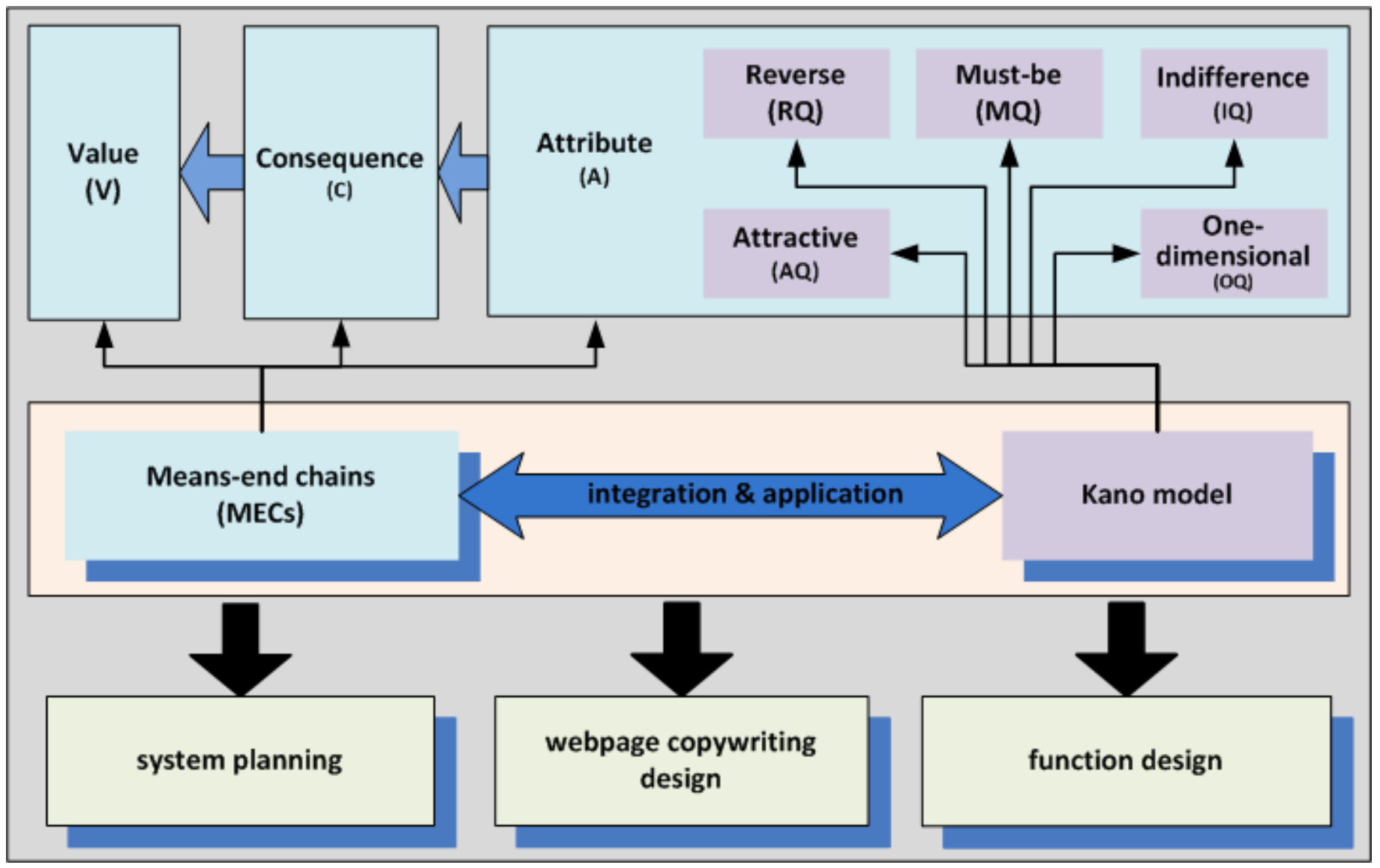

Figure 1

Research framework 


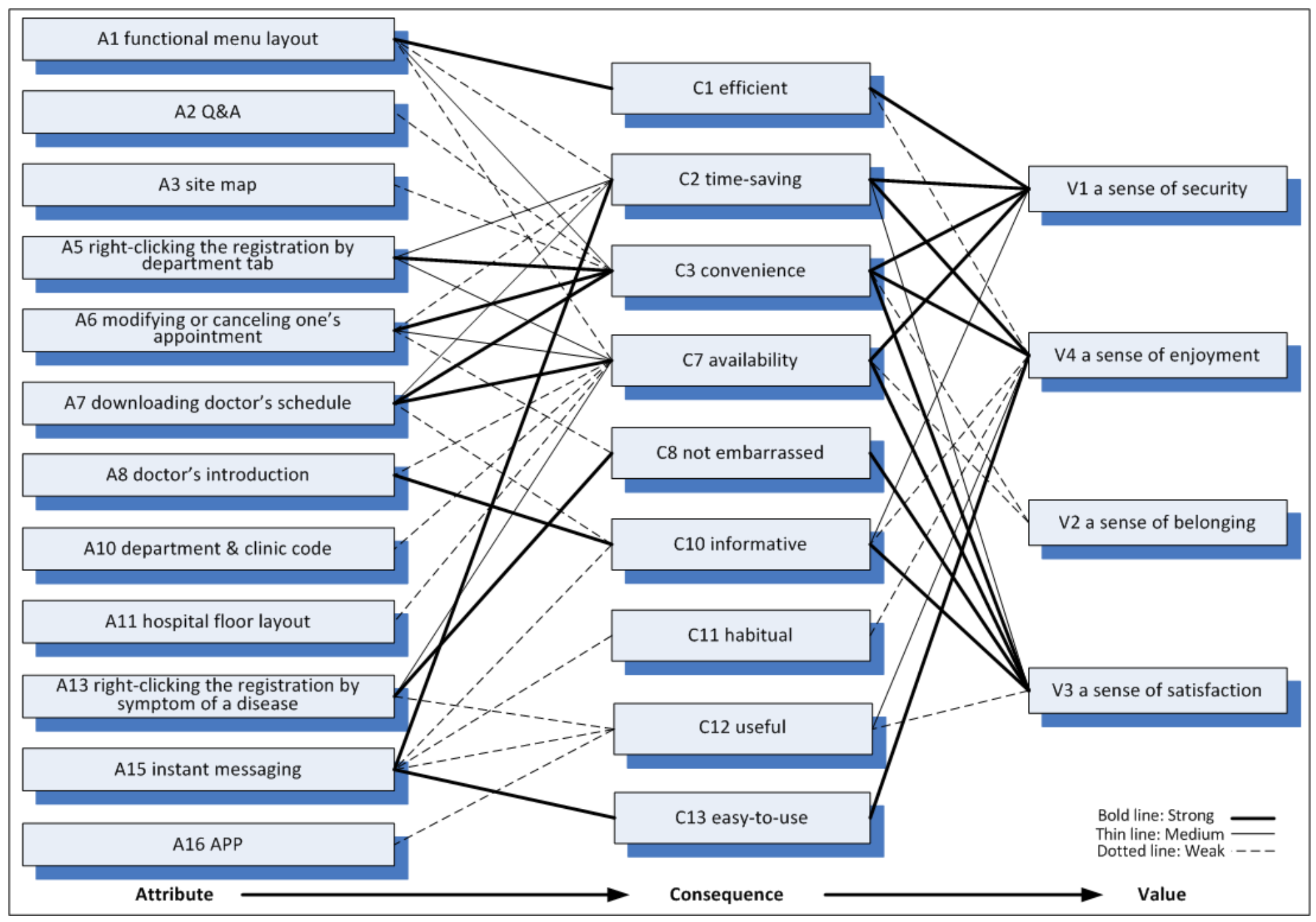

Figure 2

The hierarchical value map of hospital online registration system 


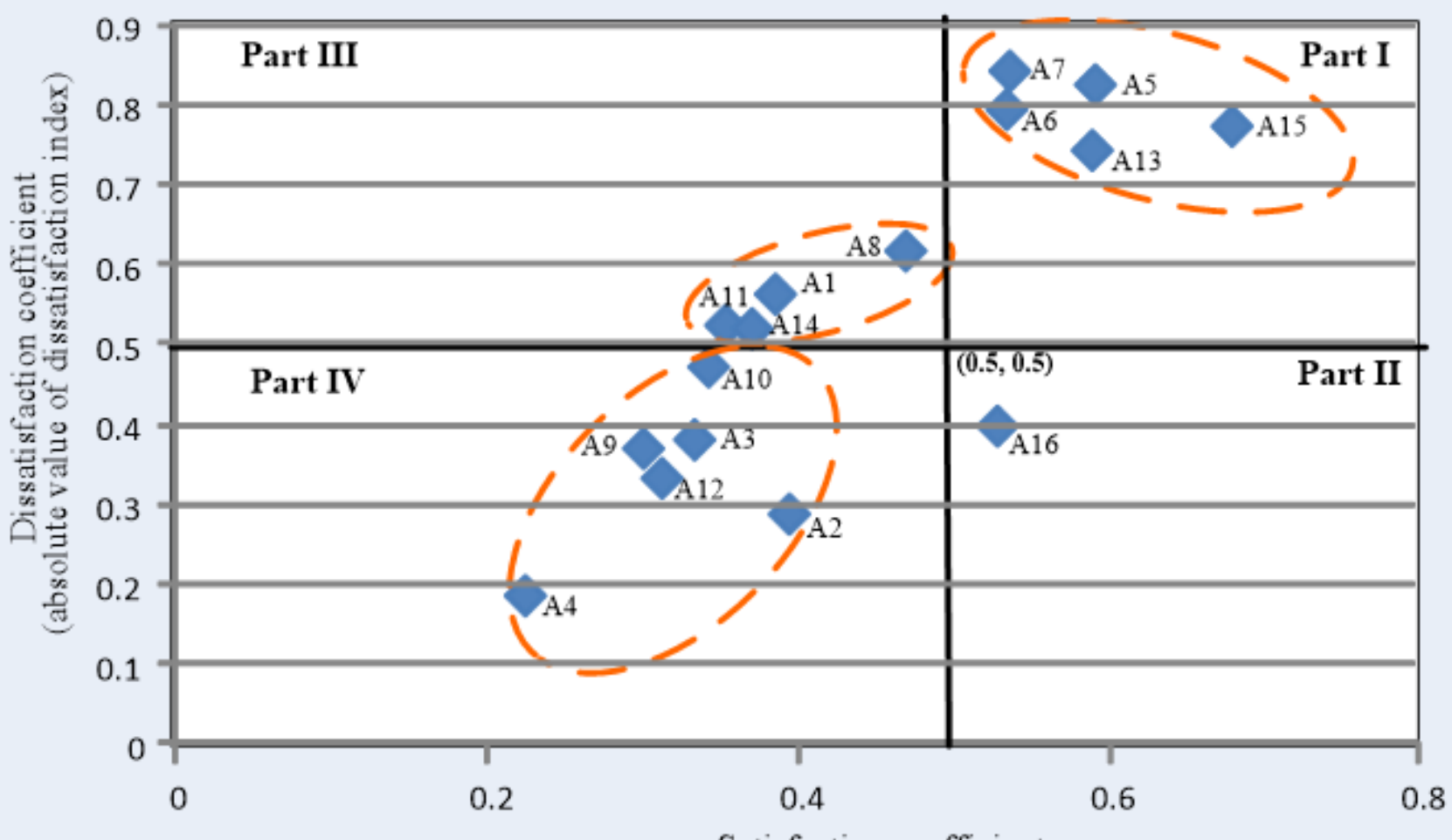

Satisfaction coefficient

Figure 3

Satisfaction impact 


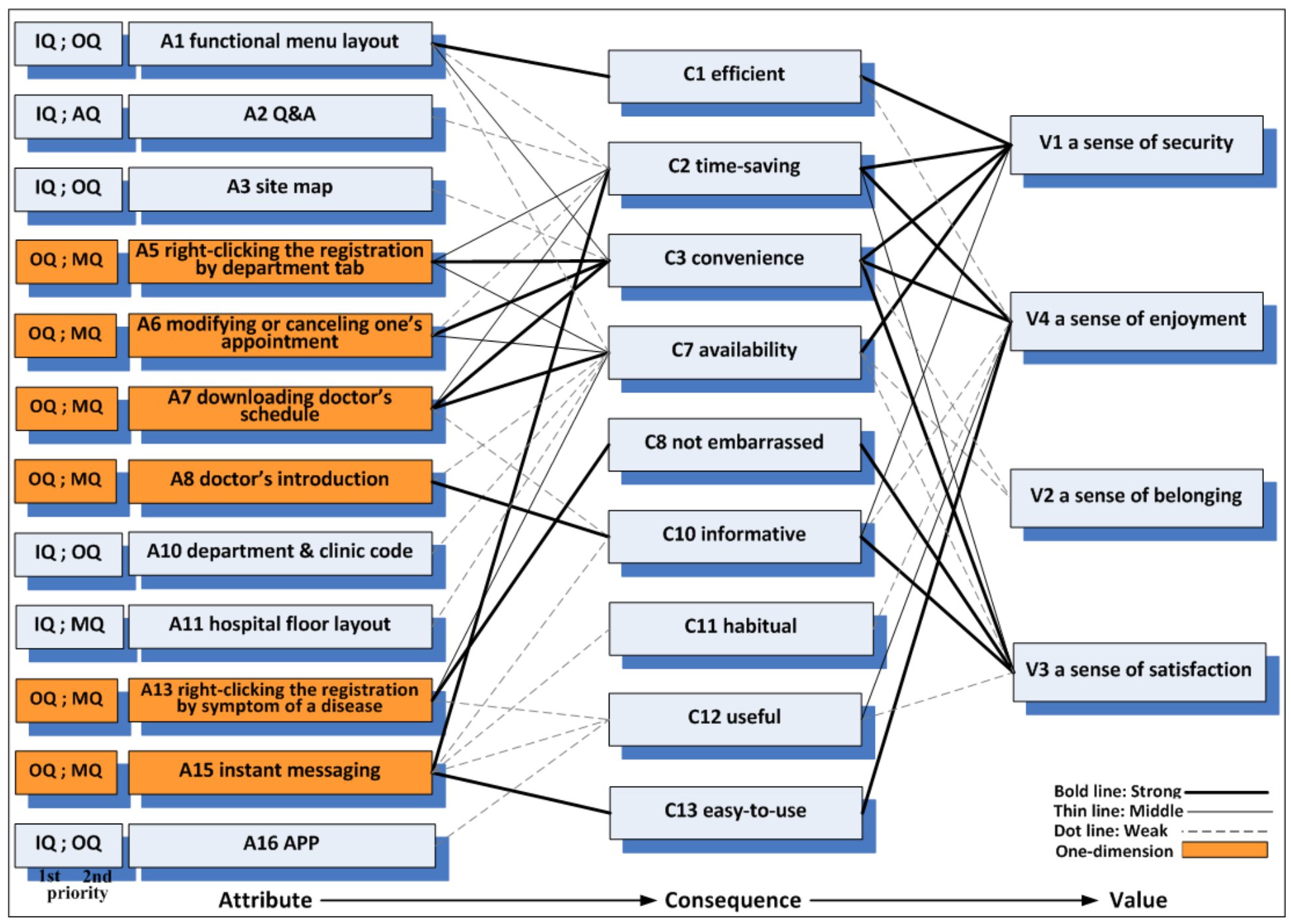

Figure 4

The Kano-MEC hierarchical map

\section{Supplementary Files}

This is a list of supplementary files associated with this preprint. Click to download.

- Reportingguideline20200105.docx 